\title{
Assessment of Agricultural Water Productivity in Arid China
}

\author{
Nana Yan ${ }^{1}$, Bingfang $W u^{1,2, * \mathbb{C}}$ and Weiwei Zhu ${ }^{1}$ \\ 1 State Key Laboratory of Remote Sensing Science, Aerospace Information Research Institute, Chinese \\ Academy of Sciences, Beijing 100094, China; yannn@radi.ac.cn (N.Y.); zhuww@radi.ac.cn (W.Z.) \\ 2 College of Resources and Environment, University of Chinese Academy of Sciences, Beijing 100049, China \\ * Correspondence: wubf@radi.ac.cn
}

Received: 7 March 2020; Accepted: 16 April 2020; Published: 18 April 2020

\begin{abstract}
The water crisis has become increasingly serious, particularly in arid and semiarid areas. Agricultural water productivity (AWP) is an important indicator for evaluating water use efficiency and agricultural water management. This study uses water consumption derived from satellite data, combined with statistical survey information, to analyze the spatiotemporal variations and driving factors of AWP at the region and county scales over the past 15 years (2002-2015) in the Turpan region (China). The results showed the increasing change trends of AWP throughout Turpan and its three counties. A multiple regression analysis was applied to evaluate AWP, agricultural production and water consumption with driving factors. The contribution of agricultural factors (fertilizer amount, pesticide use and irrigation area) was $86.3 \%$ for change of production and $93.3 \%$ for change of water consumption in Turpan. The synchronous changes associated with the similar factor contributions resulted in a nonsignificant change in AWP for the whole region. However, the significant increase in AWP in Toksun County was caused by a weakened effect of synchronous changes due to the difference between the largest contributing factors (irrigation area for production at $29.3 \%$ and temperature for water consumption at $35.4 \%$ ). The different change trends of the AWP at regional and county levels indicated that agricultural planting structure adjustment could be an effective way to improve water productivity. This paper provides objective and new information to understand the effects of AWP changes at regional and county scales, which is beneficial for irrigation agriculture development in Turpan.
\end{abstract}

Keywords: Turpan region; water productivity; trend analysis; driving factor

\section{Introduction}

The sustainable use of water resources in arid areas has become a focus of research worldwide. The Turpan Basin is the second lowest land area in the world. Due to the scarcity of precipitation in the area, the region has an extremely limited water supply, with $1437 \mathrm{~m}^{3}$ of water resources per capita in 2008 [1]. The shortage of water resources and the low utilization rate of water resources have become constraints on the social and economic development and ecological conservation of Lake Aiding. In recent years, with the increase in the population of Turpan and the increasing demand for water for industrial and agricultural uses, the increase in water consumption has aggravated the competition for water use. Moreover, the competition among water uses has become increasingly intense, and the excessive exploitation of water resources has caused the groundwater level to sharply drop, resulting in the shrinkage of Lake Aiding [2]. The fragile ecosystem has further deteriorated, and the coordinated and sustainable development of the regional environment, society and economy has become threatened. An increase in water productivity could lead to greater agricultural production, and more benefits could be obtained with less water resources. Thus, increasing water productivity is an important way to alleviate water stresses and ensures agriculture production [2]. Therefore, under limited water resource 
conditions, determining how to improve water uses efficiency is a key issue that must be solved to promote ecological restoration and agroforestry production in the Turpan region and other arid and semiarid regions.

Water productivity for agriculture is an important indicator to assess the efficiency of agricultural water use and agriculture water management [3-5]. Notably, this metric is often expressed as an output per unit of water consumption. Due to the lack of water consumption information in the Turpan area, most studies of the crop water productivity (CWP) of grapes, cotton and melon have been limited to the experimental field scale [6-9]. However, the conclusions at the field scale were biased, and thus were inappropriate for further analysis and decision making at the regional scale. For example, engineering irrigation technology played a notable role in reducing water withdrawals and improving the water use efficiency based on the irrigation water volume; however, crop water productivity based on the water consumption volume displayed no obvious variation. Many scholars have suggested that the effects of irrigation management and water-saving technologies be evaluated for an entire water system [10-15]. The water savings were assessed in northwest India and the researchers concluded that reducing leakage does not save water or reduce the rate the groundwater level decline [16]. The crop water productivity of winter wheat was studied in the Hai Basin, and the researchers found that improvements in irrigation technology did not change the status of overexploited groundwater [17]. Therefore, the objectives of reducing evapotranspiration and improving water use efficiency are important for the sustainable use of water resources.

Turpan is an extremely arid region, and water is a key factor that constrains the development of oasis agriculture. Since the 1970s, farmland irrigation has shifted from the Karez water system to modern water conservancy projects. The number of electromechanical wells has increased from 10 in 1966 to 6036 in 2009 [18]. Moreover, the groundwater volume once exceeded 200 million $\mathrm{m}^{3}$, and the groundwater level has decreased by $5-25 \mathrm{~m}$ over the past 10 years [19]. In Turpan, the water use efficiency of irrigation or the crop water productivity at the field scale as input has been used to assess agricultural water resources; however, regional information was absent. Regional information on agricultural water productivity (AWP) is urgently needed for irrigation management and water savings assessments at the regional scale. The goal of this paper is to assess the AWP at regional and county scales for Turpan through spatial and temporal changes and driving factors analysis over the past 15 years.

\section{Materials and Methods}

\subsection{Study Area}

Turpan $\left(87.53^{\circ}-91.92^{\circ} \mathrm{E}, 41.2^{\circ}-43.67^{\circ} \mathrm{N}\right)$, which is located in the east-central part of the Xinjiang Uygur Autonomous Region, is an extremely arid basin. The total area of the basin is approximately $70,000 \mathrm{~km}^{2}$ (Figure 1). Turpan has a harsh, drastic, cold desert climate with an average annual temperature of $13^{\circ} \mathrm{C}, 3200 \mathrm{~h}$ of annual sunshine, an average rainfall of $16 \mathrm{~mm}$, and potential evaporation totaling $2844.9 \mathrm{~mm}$ each year. The region has abundant solar and mineral resources, but the average

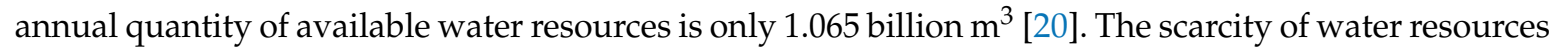
and fragile environment have become limiting factors for local social and economic development. 


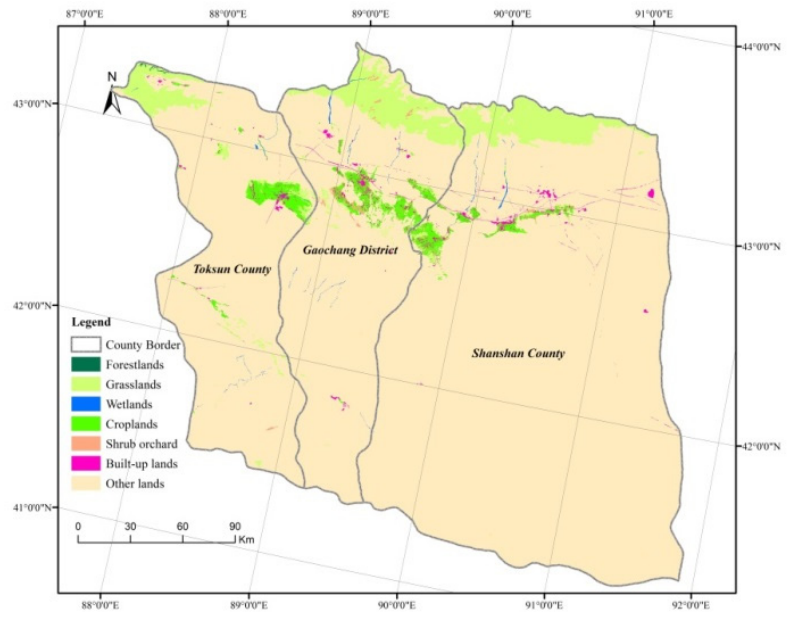

Figure 1. Location of Turpan, Gaochang District, Shanshan and Toksun Counties.

Grapes, melon and cotton are the main cultivated crops of irrigated agriculture in Turpan. According to the Statistical Yearbook, the average total crop production in Turpan in 2015 was approximately 1.38 million tons [21]. The production of grape, melon and cotton accounted for approximately $71 \%, 24 \%$ and $3 \%$, of the total production, respectively. Turpan directly controls 1 district, Gaochang, and 2 counties, Shanshan and Toksun. The crop planting structures differ in the district and counties. The percentages of grape production in Gaochang District and Shanshan County are both higher than $70 \%$, and Toksun County is dominated by cotton, with a production percentage of $80 \%$ or more.

\subsection{Data}

Monthly ET data and crop maps at 250 m resolution from 2002 to 2015 were collected from "Xinjiang Turpan Water Conservation Project", which is financed by World Bank.

Monthly ET was calculated by using ETWatch model, which integrates the energy balance model and Penman-Monteith model. Multisource remote sensing data were used to calculate the net radiation [22], soil heat flux [23], sensible heat flux, latent heat flux [24,25] and surface resistance on clear days [26]. The improved gap-filling model of the surface resistance parameter was proposed to extend the surface resistance on neighboring cloud-free days to cloudy days [27]. Then, daily ET with daily surface resistance as an input was calculated, based on the Penman-Monteith equation. The ETWatch model was widely validated using in situ EC data for seven different landscapes in arid areas, and the results showed that the RMSE and MRE between the estimated and measured ET values were $0.8 \mathrm{~mm}$ and $-7.11 \%$, respectively [27]. The validation of ET was estimated by ETWatch using in situ eddy covariance (EC) data in cotton and grape fields from 2012-2016. The coefficient of determination $\left(\mathrm{R}^{2}\right)$ between the estimated ET and EC was 0.85, and the Root Mean Square Error (RMSE) was $20.8 \mathrm{~mm} /$ month [28].

Additionally, the production, crop planting area, fertilizer, pesticide and plastic film data from 2002-2015 were obtained from the Xinjiang Investigation Annual Bulletin from 2003 to 2016 [21].

\subsection{Methodology}

\subsubsection{Water Productivity}

Crop water productivity (CWP) was defined as the ratio of crop production (economic production) to crop consumption (evaporation and transpiration) [17]. For a certain crop, the formula for CWP could be presented as follows:

$$
C W P=\frac{P r}{W C}=0.1 \times \frac{Y}{E T}
$$


where CWP is the crop water productivity of a certain crop $\left(\mathrm{kg} / \mathrm{m}^{3}\right) ; \operatorname{Pr}$ is the crop production $\left(10^{6} \mathrm{~kg}\right) ; W C$ is the crop consumption $\left(10^{6} \mathrm{~m}^{3}\right) ; Y$ is the biomass crop yield $(\mathrm{kg} / \mathrm{ha})$; and ET is crop evapotranspiration $(\mathrm{mm})$ and equal to water consumption per unit area, because the deep leakage could be omitted in the study area. The crops in this study refer to grapes, cotton and melon.

The $A W P$ was calculated and analyzed. Considering the main three cultivated crops, the formula could be rewritten as follows:

$$
A W P=0.1 \times \frac{Y_{p} \times A_{p}+Y_{c} \times A_{c}+Y_{m} \times A_{m}}{E T_{p} \times A_{p}+E T_{c} \times A_{c}+E T_{m} \times A_{m}}
$$

where $A W P$ is the agricultural water productivity of the study region $\left(\mathrm{kg} / \mathrm{m}^{3}\right) ; Y_{p}, Y_{c}$ and $Y_{m}$ are the economic yields for grapes, cotton and melon, respectively (kg/ha); $E T_{p}, E T_{c}$ and $E T_{m}$ are the crop evapotranspiration values for grapes, cotton and melon, respectively (mm); and $A_{p}, A_{c}$ and $A_{m}$ are the crop planting areas for grapes, cotton and melon, respectively (ha).

\subsubsection{Correlation and Regression Analysis}

Pearson Correlation Coefficient was calculated using Statistical Product and Service Solutions (SPSS) software to investigate the relationships between AWP, production, total water consumption and impact factors (temperature, humid, sunshine hours, fertilizer, irrigation area, etc.). Two-tailed significance test was applied, and a P value of less than 0.05 indicated a significant correlation at a confidence interval of $95 \%$.

A simple linear regression model was applied to analyze the change trends of AWP, production and water consumption with time using SPSS software. The F-test was performed at the same time to determine the significance of fitting equation at a confidence interval of $95 \%$.

In this study, a principal component regression method (PCR) was performed using SPSS to determine the contributions of two or more independent variables to the change of dependent variable in the Turpan region and three counties. Principal component analysis (PCA) represented an important step to avoid multicollinearity of independent variables. The dependent variables included the total production and total water consumption. The independent variables were the temperature, crop area and fertilizer volume.

\section{Results}

\subsection{Trend Analysis of AWP, Production And Water Consumption in the Turpan Region}

The average agricultural water productivity in Turpan from 2002 to 2015 was $2.39 \mathrm{~kg} / \mathrm{m}^{3}$, with a range of $1.88-2.81 \mathrm{~kg} / \mathrm{m}^{3}$. Among these crops, melon had the highest water productivity, with an annual average of $4.15 \mathrm{~kg} / \mathrm{m}^{3}$, and the average crop water productivities of grapes and cotton were $3.24 \mathrm{~kg} / \mathrm{m}^{3}$ and $0.189 \mathrm{~kg} / \mathrm{m}^{3}$, respectively. The CWP for different crops was reasonable compared with previous research [29-31]. The water productivity of grapes was studied at the Zhangye Irrigation Experimental Station in Gansu Province, and the results showed that the CWP of grapes under different water conditions ranged from 2.688 to $3.998 \mathrm{~kg} / \mathrm{m}^{3}$ [29]. Hu et al. (2002) investigated the water use efficiency of cotton in the Tarim Basin, and the results showed that the CWP of cotton varied from 0.17 to $0.37 \mathrm{~kg} / \mathrm{m}^{3}$ under different water conditions [30]. Zhang et al. (2013) investigated the water use efficiency of melon in greenhouses with furrow irrigation and drip irrigation in Mangubulake Village, Erpu Township, Turpan region, and the results showed that the CWP of melon for the two irrigation methods was $3.24 \mathrm{~kg} / \mathrm{m}^{3}$ and $10.17 \mathrm{~kg} / \mathrm{m}^{3}$, respectively [31].

Based on a linear regression analysis over the past 15 years, the AWP changed in weak upward trend with the slope of $0.0298 \mathrm{~kg} / \mathrm{m}^{3}$ (Figure 2). The total production of the three cultivated crops (grape, cotton and melon) in Turpan was 1,384,400 tons in 2015, an increase of approximately $123 \%$ compared with that in 2002, representing a significant growth trend over the past 15 years (slope $=4.9888 \times 10^{7} \mathrm{~kg}$, $\left.\mathrm{R}^{2}=0.835, \mathrm{P}<0.05\right)$. An analysis of two of the input variables of total production, namely the area 
and yield, showed that the cultivated crop area has significantly increased over the past 15 years (slope $=2.3 \mathrm{kha}, \mathrm{R}^{2}=0.87, \mathrm{P}<0.05$ ), and the planting area in 2015 was $92 \%$ higher than that in 2002. In terms of the yield, although the average yield in 2015 increased by $16 \%$ compared with that in 2012 , the yield increase over the past 15 years was not significant (slope $=186 \mathrm{~kg} / \mathrm{ha}, \mathrm{R}^{2}=0.242$, $\mathrm{P}>0.05)$. The total agricultural water consumption in Turpan averaged 409 million $\mathrm{m}^{3}$ and increased significantly at a rate of 15.7 million $\mathrm{m}^{3}$ per year over the past 15 years $\left(\mathrm{R}^{2}=0.666, \mathrm{P}<0.05\right)$; however, the water consumption per unit area (ET) fluctuated, and the slight decreasing trend was not significant. The increase in crop area led to simultaneous increases in total production and water consumption, which were important reasons for the insignificant trend of AWP at the region scale.

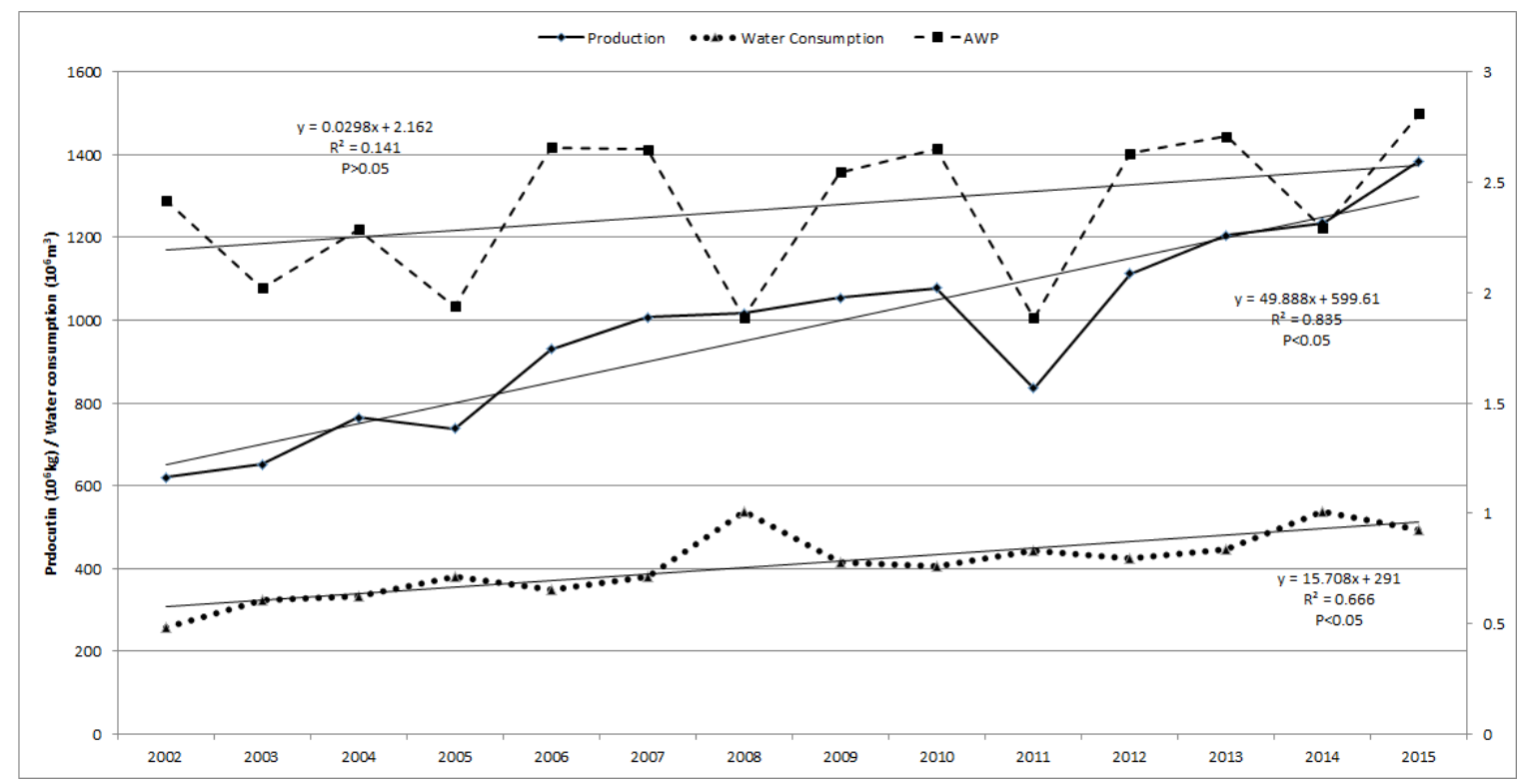

Figure 2. Time-series change of agricultural water productivity (AWP), production and water consumption in Turpan, 2002-2015.

\subsection{Trend Analysis of AWP, Production and Water Consumption by County and District}

The average agricultural water productivity in the Gaochang District, Shanshan County and Toksun County from 2002 to 2015 was 2.62, 3.15 and $0.72 \mathrm{~kg} / \mathrm{m}^{3}$, respectively. A linear regression analysis was used to analyze the trends of various factors. There are obvious differences among the two counties and district (see Table 1). Notably, the trend of AWP in Gaochang District is not obvious. The AWP displayed a marginal significant increasing trend in Shanshan County, and a significant increasing trend in Toksun County. The trends of total agricultural water consumption and total production were generally similar in different counties, and significant increasing trends were observed.

In Gaochang District and Shanshan County, the grape planting area accounted for 73-75\% of the area (Figure 3), and the proportions of grape production and water consumption were the largest. The cotton planting area and associated water consumption ranked second. The melon planting area was slightly lower than those of the other two crops, although the production ranked second due to the high average yield $(27,485 \mathrm{~kg} / \mathrm{ha})$ compared with that of grapes $(25,277 \mathrm{~kg} / \mathrm{ha})$ and cotton $(1267 \mathrm{~kg} / \mathrm{ha})$. In the past 15 years, the average yields of grapes, cotton and melons in Shanshan County displayed significant growth trends, and in Gaochang District, only grapes exhibited an increasing trend. The cotton and melon yields decreased in Gaochang District. Moreover, the increasing slope of ET was higher in Gaochang District, and the combined effect of the two factors led to a higher growth rate of AWP in Shanshan County. 
In Toksun County, cotton is the main crop, and the proportions of grapes and melon were less than 15\% (Figure 3). The average ET displayed decreasing trend, while crop yield showed the non-significant increasing trend. Both the two factors resulted in the significant increase in annual AWP by $0.018 \mathrm{~kg} / \mathrm{m}^{3}$. Due to the lower yield of cotton $(1379 \mathrm{~kg} / \mathrm{ha})$ compared with grape and melon $(28,227 \mathrm{~kg} / \mathrm{ha})$, the growth rate of total production in Toksun County was much smaller than that in Gaochang District and Shanshan County. This difference could be the main reason why the growth rate of the average AWP in Toksun was lower than that in the other two counties.

Although there were widespread increasing crop areas in district and counties, the opposite change trends of ET and yield in Toksun County improved the regional AWP through the offset effect of crop area increase, to some extent. The increasing use of plastic film might be one of main reasons for ET reduction. There were significant increasing trends of water productivity for cotton (slope $=0.003 \mathrm{~kg} / \mathrm{m}^{3}, \mathrm{R}^{2}=0.21, \mathrm{P}<0.1$ ), melon (slope $=0.059 \mathrm{~kg} / \mathrm{m}^{3}, \mathrm{R}^{2}=0.31, \mathrm{P}<0.05$ ) and grapes (slope $=0.239 \mathrm{~kg} / \mathrm{m}^{3}, \mathrm{R}^{2}=0.42, \mathrm{P}<0.05$ ) in Toksun County, due to the decreasing ET and increasing yield over past 15 year. The change of water productivity for grapes in Gaochang District and Shanshan County was not obvious, due to the increase in yield and ET. Considering the importance of the grape in Turpan, the development of water saving technology for grapes is a key direction.

Table 1. Average values and annual change rates in AWP, production, water consumption and crop area in the counties and district of Turpan during 2002-2015.

\begin{tabular}{|c|c|c|c|c|c|c|c|c|}
\hline \multirow{2}{*}{ Turpan } & \multicolumn{2}{|c|}{$\operatorname{AWP}\left(\mathrm{kg} / \mathrm{m}^{3}\right)$} & \multicolumn{2}{|c|}{ Production $\left(10^{6} \mathrm{~kg}\right)$} & \multicolumn{2}{|c|}{$\begin{array}{l}\text { Water Consumption } \\
\left(10^{6} \mathrm{~m}^{3}\right)\end{array}$} & \multicolumn{2}{|c|}{ Crop Area (ha) } \\
\hline & Average & $\begin{array}{l}\text { Annual } \\
\text { Slope }\end{array}$ & Average & $\begin{array}{l}\text { Annual } \\
\text { Slope }\end{array}$ & Average & $\begin{array}{l}\text { Annual } \\
\text { Slope }\end{array}$ & Average & $\begin{array}{c}\text { Annual } \\
\text { Slope }\end{array}$ \\
\hline Gaochang & 2.62 & 0.026 & 453.30 & $21.45 *$ & 1741962 & $6.43 *$ & 23978 & $816^{*}$ \\
\hline Shanshan & 3.15 & $0.055 \#$ & 463.22 & $22.75 *$ & 1471710 & $4.58 *$ & 21271 & $620 *$ \\
\hline Toksun & 0.72 & $0.018 *$ & 60.26 & $4.11 *$ & 832665 & 3.84 * & 11141 & $698 *$ \\
\hline
\end{tabular}

Note: * Significant at $\alpha=0.05$; \# Significant at $\alpha=0.1$.

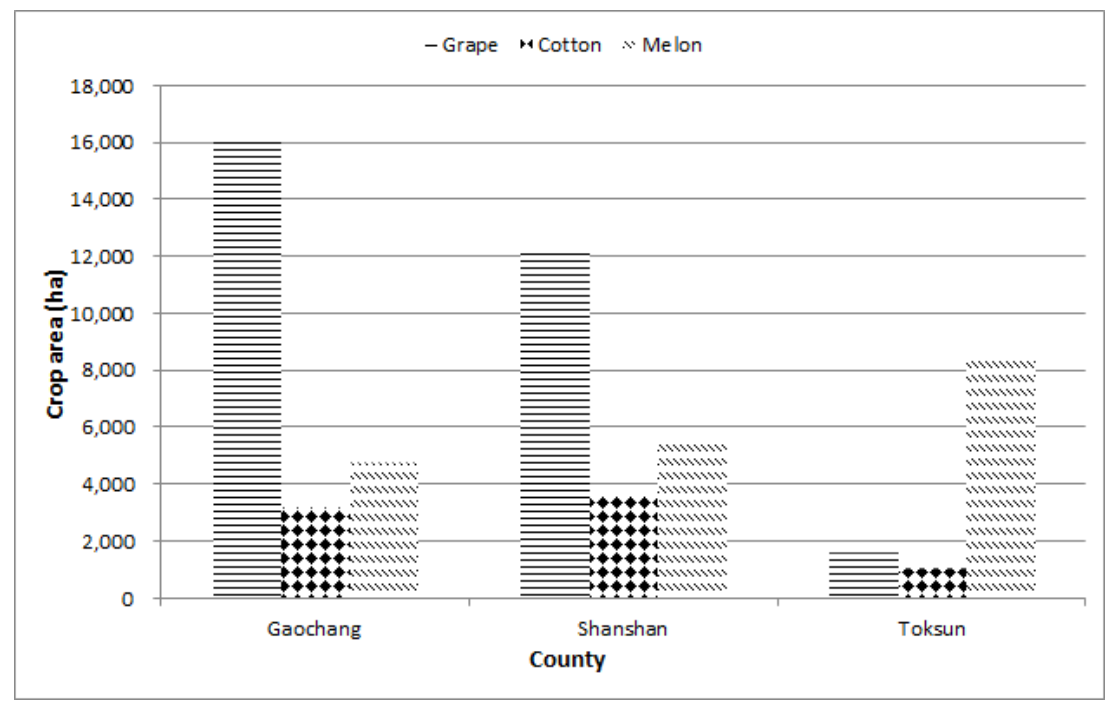

Figure 3. Average crop areas of grape, cotton and melon in the counties and district of Turpan.

\subsection{Impact Factor Analysis of AWP}

To compare the relationships between water consumption, production and AWP, the ET during the crop growing season from April to October in the farmland area was first summed to obtain the total ET in the growing season. A correlation analysis was conducted. The results showed a significant 
positive correlation between the average production and agricultural water productivity in Turpan $(\mathrm{R}=0.822, P<0.05)$ and a negative correlation between water consumption and AWP $(\mathrm{R}=-0.701$, $P<0.05)$.

Many factors affected the AWP, including meteorological elements (e.g., temperature, wind speed, humidity and sunshine hours) and agricultural inputs (e.g., the fertilizer amount, pesticide use, film cover and the irrigation area). Due to the extremely arid climate of Turpan, the amount of precipitation is lower than $20 \mathrm{~mm}$, and irrigation is needed to meet the sowing and normal growth requirements of crops. Therefore, the crop area is equivalent to the actual irrigated area. The average values of temperature, wind speed, humidity and number of sunshine hours during the growing season (April-October) were obtained. The correlation analysis involving these factors and AWP in Turpan region and three counties is shown in Table 2. The pesticide use and film data were not included in three counties, due to limited data availability. The correlations between water productivity and various impact factors were not significant in Turpan region and Gaochang County; The AWP in Shanshan and Toksun County had significant correlations with temperature and fertilizer.

Table 2. Pearson correlation coefficients involving AWP, production, water consumption and impact factors in Turpan and three counties.

\begin{tabular}{|c|c|c|c|c|c|c|c|c|c|}
\hline Region & Item & Temperature & Humidity & $\begin{array}{l}\text { Sunshine } \\
\text { Hours }\end{array}$ & $\begin{array}{l}\text { Wind } \\
\text { Speed }\end{array}$ & $\begin{array}{l}\text { Fertilizer } \\
\text { Amount }\end{array}$ & $\begin{array}{l}\text { Pesticide } \\
\text { Use }\end{array}$ & $\begin{array}{l}\text { Film } \\
\text { Cover }\end{array}$ & $\begin{array}{c}\text { Irrigation } \\
\text { Area }\end{array}$ \\
\hline \multirow{3}{*}{ Gaochang } & AWP & 0.309 & 0.180 & -0.290 & 0.239 & 0.037 & & & 0.364 \\
\hline & Production & 0.870 & -0.127 & 0.346 & 0.861 & 0.864 & & & 0.838 \\
\hline & $\begin{array}{c}\text { Water } \\
\text { consumption }\end{array}$ & 0.739 & -0.262 & 0.650 & 0.754 & 0.925 & & & 0.612 \\
\hline \multirow{3}{*}{ Shanshan } & AWP & 0.552 & -0.332 & -0.237 & -0.319 & 0.448 & & & 0.316 \\
\hline & Production & 0.768 & -0.283 & -0.128 & -0.429 & 0.769 & & & 0.863 \\
\hline & $\begin{array}{c}\text { Water } \\
\text { consumption }\end{array}$ & 0.567 & -0.046 & 0.061 & -0.345 & 0.561 & & & 0.880 \\
\hline \multirow{3}{*}{ Toksun } & AWP & 0.663 & -0.128 & 0.216 & 0.326 & 0.453 & & & 0.399 \\
\hline & Production & 0.924 & -0.346 & 0.612 & 0.394 & 0.534 & & & 0.889 \\
\hline & $\begin{array}{c}\text { Water } \\
\text { consumption }\end{array}$ & 0.786 & -0.354 & 0.683 & 0.237 & 0.379 & & & 0.891 \\
\hline \multirow{3}{*}{ Turpan } & AWP & 0.114 & -0.094 & -0.255 & 0.037 & 0.276 & 0.099 & $0.252 *$ & 0.007 \\
\hline & Production & 0.842 & -0.348 & 0.014 & -0.552 & 0.843 & 0.812 & $0.674 *$ & 0.923 \\
\hline & $\begin{array}{c}\text { Water } \\
\text { consumption }\end{array}$ & 0.828 & -0.308 & 0.173 & -0.619 & 0.677 & 0.770 & 0.527 * & 0.942 \\
\hline
\end{tabular}

Note: Bold denote significant relations at $\alpha=0.05 .{ }^{*}$ The available film covers data in 2006-2008, 2011-2015.

A Pearson correlation analysis was also performed for the production and water consumption, which are key components of water productivity (Table 2), and the scatter point charts of factors with significant correlations for Turpan Region are also shown in Figure 4. The water consumption in the growing season was significantly positively correlated with the average temperature, fertilizer amount, pesticide use and irrigation area, and was significantly negatively correlated with the average wind speed. Among these factors, the correlation coefficient between total water consumption and irrigation area was the highest $(R=0.942)$, followed by those for average temperature, chemical fertilizer application and pesticide use. The total production and irrigation area, fertilizer amount, amount of pesticides used and average temperature were highly correlated, and the correlation coefficients ranged from 0.8 to 1.0. The total production was also correlated with the area covered by plastic film, to lesser degrees. Over the past 15 years, crop water consumption and crop production have been affected by both meteorological and agricultural input factors. An increase or decrease in the same direction may be the main reason for the lack of a significant trend in regional AWP. 


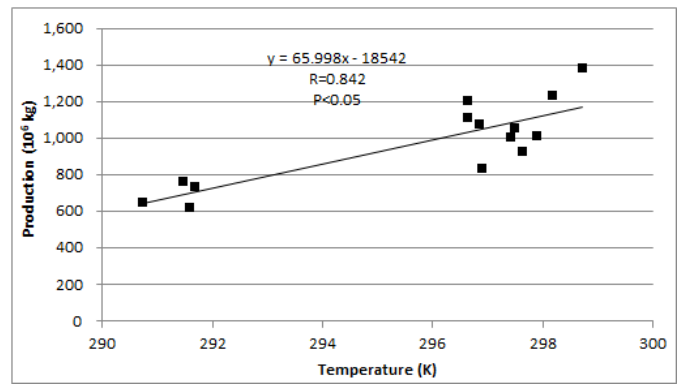

(a) Temperature and Production

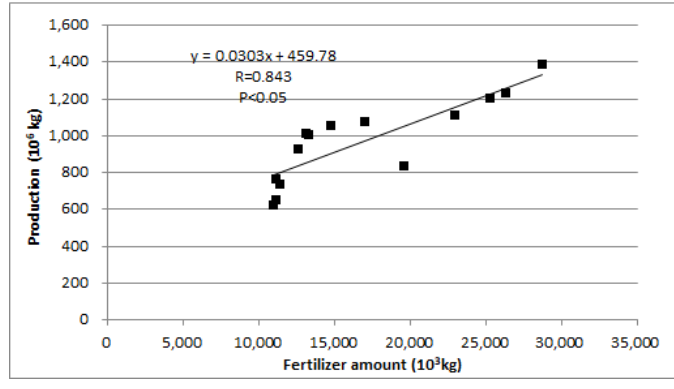

(c) Fertilizer Amount and Production

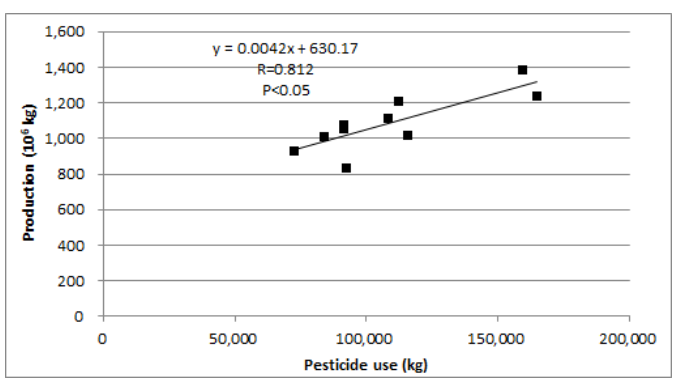

(e) Pesticide Use and Production

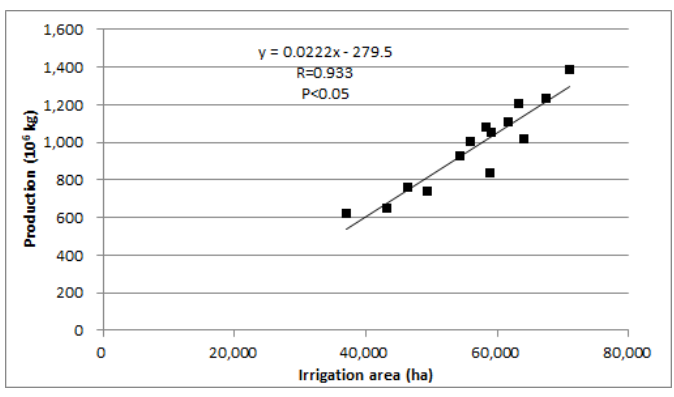

(g) Irrigation Area and Production

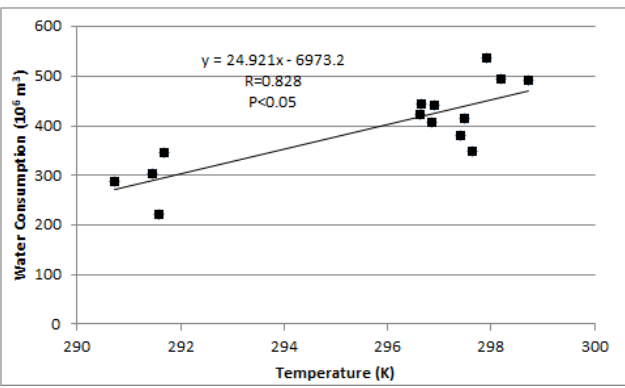

(b) Temperature and Water Consumption

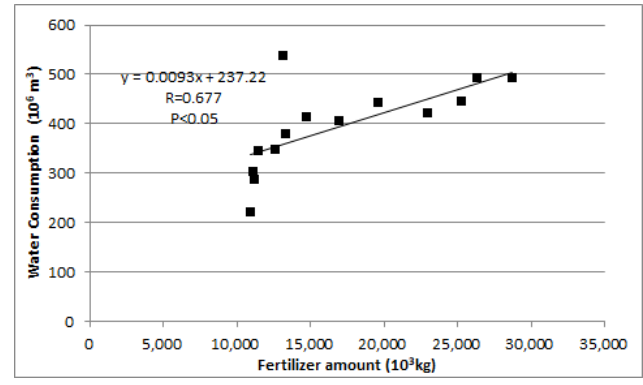

(d) Fertilizer Amount and Water Consumption

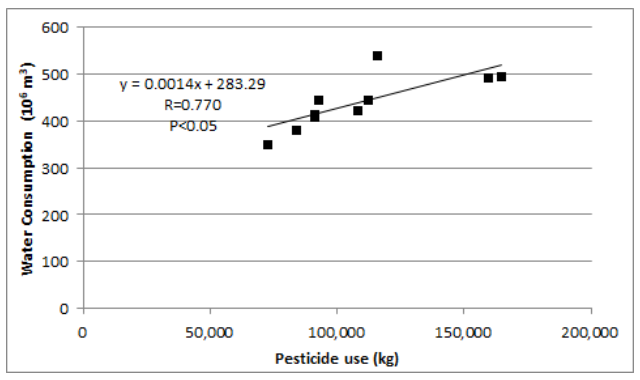

(f) Pesticide Use and Water Consumption

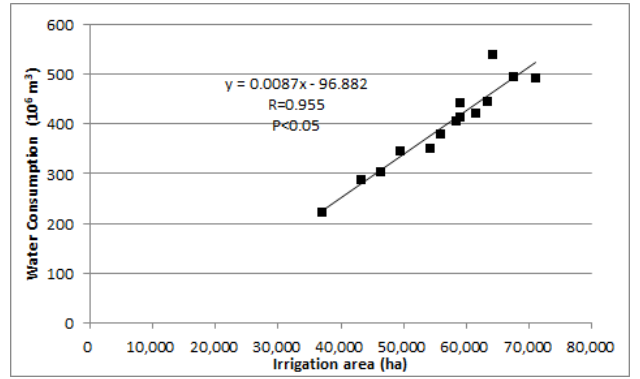

(h) Irrigation Area and Water Consumption

Figure 4. Scatter points among production, water consumption and impact factors in Turpan Region (temperature, fertilizer amount, film cover, and irrigation area).

Generally, the average temperature, fertilizer amount, pesticide use and irrigation area significantly correlated with both production and water consumption in three counties. In Toksun County, 
the sunshine hours had good correlations with water consumption and production. The wind speed significantly correlated with production and water consumption in Gaochang District. The factors with significant correlation with AWP, water consumption and production for Turpan, and the three counties were selected to further analysis.

\subsection{Contribution Analysis of the Main Factors That Influenced AWP, Production and Water Consumption}

A principle component regression was used to identify the contribution of main factors to the water consumption and production change in Turpan, as well as the two counties and district. Table 3 presents the regression equations for Turpan. In Turpan, the driving factors, including temperature, wind speed, fertilizer amount, pesticide use and irrigation area, explained $86.6 \%$ of the change in production. The contribution of agricultural factors (the fertilizer amount, pesticide use and irrigation area) reached $86.3 \%$, and each of the three factors accounted for about $1 / 3$ weight. The contribution of the climate factors (temperature and wind speed) was $13.7 \%$. On the other hand, the same driving factors set explained $78.9 \%$ of the change in the total water consumption for three crops. The contributions of agricultural and climate factors were $93.3 \%$ and $7.7 \%$, respectively. The irrigation area was the driving factor with the highest contribution rate of $32.4 \%$. For an irrigation area change of $1 \%$, the total water consumption increased by $0.220 \%$. Therefore, the combined effect of the same driving factors set caused total production and total water consumption to change in the same direction, which was the reason for the weak increasing on regional AWP.

The relationships between the AWP, production and water consumption and driving factors in the three counties were also performed (Table 3). A simple linear regression model was applied to AWP after multicollinearity test among factors for Shanshan and Toksun County. Although the regression equation of AWP passed the F test, the change of the factors could only explain $32.8 \%$ and $34.9 \%$ of the change in AWP for Shanshan County and Toksun County, respectively. Temperature and fertilizer use had positive contributions to the AWP.

The contribution of agricultural factors to water consumption and production in Gaochang District was $40.5 \%$ and $49.0 \%$, respectively. The irrigation area was the factor with the largest contribution to changes of water consumption and agricultural production at percentages of $22.1 \%$ and $26.0 \%$, respectively. The synchronous changes of agricultural production and water consumption were caused by the similar driving factors set and the same factor with the largest contribution, thus leading to nonsignificant changes in the AWP trends in Gaochang District.

In Shanshan County, the contribution of agricultural factors (fertilizer use amount and irrigation area) on changes of production and water consumption in this county was $72.2 \%$ and $68.5 \%$, respectively. The irrigation area was largest contribution factor to changes of water consumption at $36.7 \%$, while the fertilizer use had the largest contribution to changes of agricultural production at $36.4 \%$. The different factors with the largest contribution may account for the marginal significant increase in the AWP in this county.

The driving factors sets to production and water consumption in Toksun County were different compared with that of the other two counties. The contribution of agricultural factors to water consumption and production was $43.5 \%$ and $35.0 \%$, respectively. The largest contributing factor to changes of production was irrigation area, at $29.3 \%$, while the largest contributing factor to water consumption was temperature, at $35.4 \%$. The contribution differences of factors could be the reason why the AWP in Toksun County showed a significant upward trend. 
Table 3. Multiple linear regression equations for AWP, production and total water consumption in whole Turpan and three counties.

\begin{tabular}{|c|c|c|c|c|}
\hline $\begin{array}{l}\text { Dependent } \\
\text { Variables }\end{array}$ & Turpan Region & Gaochang District & Shanshan County & Toksun County \\
\hline AWP & & & $\begin{array}{c}\text { Yawp }=0.455 \mathrm{Xt}+0.302 \\
\mathrm{Xf} \\
\mathrm{R}^{2}=0.328 \\
\mathrm{P}<0.05\end{array}$ & $\begin{array}{c}\text { Yawp }=0.599 \mathrm{Xt}+0.114 \\
\text { Xf } \\
\mathrm{R}^{2}=0.349 \\
\mathrm{P}<0.05\end{array}$ \\
\hline Production & $\begin{array}{c}\text { Ypr }=0.162 X_{t}-0.033 X_{w} \\
+0.277 X_{f}+0.284 X_{p}+ \\
0.259 X_{i}\end{array}$ & $\begin{array}{c}\mathrm{Ypr}=0.261 \mathrm{Xt}+0.255 \\
X \mathrm{w}+0.230 \mathrm{Xf}+0.260 \mathrm{Xi}\end{array}$ & $\begin{aligned} \mathrm{Ypr}= & 0.328 \mathrm{Xt}+0.429 \mathrm{Xf} \\
& +0.421 \mathrm{Xi}\end{aligned}$ & $\begin{array}{c}\mathrm{Ypr}=0.541 \mathrm{Xt}+0.377 \mathrm{Xs} \\
+0.548 \mathrm{Xf}+0.403 \mathrm{Xi}\end{array}$ \\
\hline & $\begin{aligned} \mathrm{R}^{2} & =0.866 \\
\mathrm{P} & <0.05\end{aligned}$ & $\begin{aligned} \mathrm{R}^{2} & =0.857 \\
\mathrm{P} & <0.05\end{aligned}$ & $\begin{aligned} \mathrm{R}^{2} & =0.934 \\
\mathrm{P} & <0.05\end{aligned}$ & $\begin{aligned} \mathrm{R}^{2} & =0.842 \\
\mathrm{P} & <0.05\end{aligned}$ \\
\hline Water consumption & $\begin{array}{c}Y w c=0.210 X t-0.165 X w \\
+0.197 X f+0.216 X p+ \\
0.220 X i\end{array}$ & $\begin{array}{c}\mathrm{Ywc}=0.214 \mathrm{Xt}+0.214 \\
\mathrm{Xw}_{\mathrm{w}}+0.160 \mathrm{Xs}+0.179 \mathrm{Xf} \\
+0.221 \mathrm{Xi}\end{array}$ & $\begin{array}{c}Y w c=0.312 X t+0.316 \\
X f+0.3642 X i\end{array}$ & $\begin{array}{c}Y w c=0.359 X t+0.300 \\
X s+0.355 X i\end{array}$ \\
\hline & $\begin{aligned} R^{2} & =0.789 \\
P & <0.05\end{aligned}$ & $\begin{aligned} \mathrm{R}^{2} & =0.699 \\
\mathrm{P} & <0.05\end{aligned}$ & $\begin{aligned} \mathrm{R}^{2} & =0.616 \\
\mathrm{P} & <0.05\end{aligned}$ & $\begin{aligned} \mathrm{R}^{2} & =0.790 \\
\mathrm{P} & <0.05\end{aligned}$ \\
\hline
\end{tabular}

Note: Ypr is the standardized production, Yawp is the standardized AWP, $\mathrm{YW}_{\mathrm{W}}$ is the standardized water consumption, $\mathrm{Xt}_{\mathrm{t}}$ is the standardized temperature, $\mathrm{X}_{\mathrm{w}}$ is the standardized wind speed, $\mathrm{Xf}$ is the standardized fertilizer use amount, $\mathrm{X} \mathrm{p}$ is the standardized pesticide use, and $\mathrm{X}$ is the standardized irrigation area.

\section{Discussion}

Irrigation agriculture is the basis for the survival and development of the Turpan region. Agriculture is a major water user, and water has become the primary factor restricting regional economic development. The sustainable development of agriculture is the basis for economic development in the Turpan region. AWP is a comprehensive indicator of the level of agricultural production and the scientific and rational use of agricultural water. Additionally, AWP is an important component of water-saving irrigation and efficient agricultural development.

Water use efficiency is normally expressed as the ratio of the crop yield to the volume of applied irrigation water, because the relevant water use data are relatively easy to acquire. However, this approach neglects information regarding the recharge and reuse of water and may overestimate the water use efficiency at the regional scale. An increase in irrigation efficiency (IE) at the farm scale fails to increase the water availability at a watershed and basin scale, and the increases in IE must be accompanied by robust water accounting and measurement in regional scale were suggested [15]. In this study, rather than using the quantity of irrigation water, water consumption was used to calculate AWP. The AWP in the Turpan Region and Gaochang District showed a nonsignificant increasing trend. Although the irrigation area is an important impact factor in production and water consumption, it is not the main driving factor to AWP. An increase in the irrigation area definitely played a positive role in increasing agricultural production, but it was also the largest contributing factor for increasing water consumption. Measures need be taken to control the increasing trends of crop area and total water consumption. Similar conclusions were drew based on an analysis of the spatial and temporal characteristics of winter wheat water productivity in the Hai Basin [17]. They found that simultaneous increases in the production and water consumption stabilized AWP at the regional level, thus providing insights on water saving measures and investments for agriculture development.

To improve AWP, the tradeoff between crop or economic growth and water resource sustainable utilization needs to be considered. Increasing production under the limit of total agriculture water consumption represents a difficult task for agricultural development in the Turpan region. Agricultural planting structure adjustments have been considered an effective method of improving water productivity, and could adjust the water allocation from the lower water productivity to higher productivity [32]. However, it is not easy to realize this, due to traditional crop cultivation customs and risk tolerance. Farmers lack motivation to implement water saving practices because of the lower water price in the Turpan Region. Undoubtedly, water rights and water markets have been considered when attempting to adapt to water scarcity [33]. Many researchers have found that the participation in water markets improves water use efficiency in the agriculture sector and promotes economic water resource 
use efficiency among different sectors [34-36]. The water buyers and water sellers are more efficient in using water than farmers who do not participate in water markets. Water rights holders engaged in agriculture can achieve enhanced benefits by forming crop-type cooperatives and implementing demand-based allocation redistribution rulesets [34].

Notably, a significant increase in AWP was only shown in Toksun County over the past 15 years. The driving factor with the largest contribution to production and water consumption was temperature $(35.4 \%)$ and irrigation area (28.7\%). Except for the weather impacts, the increased use of plastic film may have led to the decreasing ET for crops. Due to the limit availability of data on plastic film use at the county levels, this factor was not included in the PCR analysis. The experience and knowledge of the agricultural water saving measures and crop planting structure in this county should be further analyzed and summarized as a good pilot for agriculture development. Moreover, the largest percentage of cotton yield in the county was lower than that of melon and grape. Production increases could occur without increasing water consumption, which would improve the AWP. The optimization of crop planting structures needs to consider the adaptability limits of soil and climate. On the other hand, water rights and corresponding markets are worthy of study for water reallocation among three counties in aim to improve water use efficiency in the whole region.

The irrigation water productivity in the Hexi Corridor were analyzed and the results showed that fertilizer application, films, pesticides, temperature and solar radiation were significantly correlated with irrigation water productivity [37]. Additionally, the contribution of agronomic measures (fertilizer application, surface film and the supply area per unit of irrigation water) was greater than that of climate factors. In this study, the temperature and fertilizer amount are significantly correlated with the AWP in Shanshan County and Toksun County. A similar conclusion was found for production change, and it was significantly correlated with the amount of fertilizer applied, plastic films, pesticide use, temperature and the irrigation area. The irrigation water and ET were used to calculate the water use efficiency and water productivity for three water conservation project areas in three counties of Turpan region, and the results showed obvious increasing trends of these two efficiency variables from 2010 to 2016 [2]. Water productivity could be improved at small scales for some measures, such as drip systems and plastic film application. The regional analyses of AWP can be important supplement information for decision-making on government investments. Further improvements in water use efficiency in the whole region could occur through optimization of the crop planting structure [2].

In addition, due to the limitations of crop yield information, only the average AWP of the entire region and counties were analyzed. An analysis of AWP at the field or village scale should be encouraged if the yield information could be estimated from remote sensing.

\section{Conclusions}

Under the condition of limited water resources, analyses of the AWP in extremely arid regions play an important role in the development of oasis agriculture in these regions. This study uses an ET data set derived from remote sensing; meteorological data from a meteorological site; and crop area, production and agronomic measures from the statistical yearbooks to analyze the changes in total water consumption, total production and AWP in Turpan and three counties over the past 15 years (2002-2015). The trends and the driving factors were analyzed, and the following conclusions were obtained.

(1) In Turpan, the average annual AWP is $2.39 \mathrm{~kg} / \mathrm{m}^{3}$, with a range of $1.88-2.81 \mathrm{~kg} / \mathrm{m}^{3}$. Overall, the weak increasing rate of AWP was $0.0298 \mathrm{~kg} / \mathrm{m}^{3}$ over the past 15 years in Turpan, and the nonsignificant increasing trend indicated that the improvement of agricultural water use efficiency at the basin scale was limited. The significant increase trends of total production and water consumption were mainly due to increasing irrigation area. Measures need be implemented to control the total water consumption in order to cope with serious water problems.

(2) There were spatial differences in the AWP trends at the county scale. At the county and district scales, only the AWP in Toksun County displayed a significant increasing trend. However, 
Gaochang District and Shanshan County exhibited higher average values and growth rates of AWP than Toksun County, because of different crop planting structures. This result implied that a potential effective way to improve AWP at the regional or county scale is to adjust the planting structure.

(3) In Turpan, the total crop production and total water consumption displayed significant growth trends, with $4.9888 \times 10^{7} \mathrm{~kg}$ and 15.7 million $\mathrm{m}^{3}$ of annual growth, respectively. The multiple linear regression analysis between production and water consumption with the impact factors explained the non-significant change of AWP. The agricultural factors (fertilizer amount, pesticide use and irrigation area) have made the largest contribution to production and water consumption, at $86.3 \%$ and $93.3 \%$, respectively. The combined effect of the same driving factors caused the synchronous changes of agricultural production and water consumption. At the county scale, only Toksun County displayed larger contribution differences of the major driving factors. The largest contributing factor to changes of production was irrigation area at $29.3 \%$, while the largest contributing factor to water consumption was temperature at $35.4 \%$. The AWP in Toksun County exhibited a significant increasing trend, due to the weakened effect of synchronous changes.

In summary, this study analyzed the current status and trend change of the AWP at the regional and county scales. The analyses of the temporal and spatial trends and driving factors provide objective and new information regarding crop production, water consumption and AWP. The results are useful information that can compensate for the data gaps on improving water productivity at the field, county and region scales, and thus can be beneficial for irrigation agriculture development in extremely arid regions and oasis areas.

Author Contributions: N.Y. contributed to the CWP calculation, analysis and assessment and draft the paper. B.W. conceived the outline of this paper and discussion part. W.Z. provided the ET series data and crop maps, and also helped to analyze the spatiotemporal change of water consumption. All co-authors helped revise the manuscript. All authors have read and agreed to the published version of the manuscript.

Funding: This research was supported by National Key Research and Development Program of China (Grant No. 2016YFC0501601), and National Natural Scientific Foundations of China (Grant No. 41991232).

Acknowledgments: The meteorological data, crop map and monthly ET data from 2002-2015 were collected from the project of "Xinjiang Turpan Water Conservation Project".

Conflicts of Interest: The authors declare no conflicts of interest.

\section{References}

1. Wei, Q.; Li, B.; Liu, L. Research on rational exploitation and protection of water resources of Turpan Basin. Ground Water 2013, 35, 51-56.

2. Li, J.; Li, X. Analysis of Water Resources Management Practice in Turpan Based on Water Consumption Control. Haihe Water Resour. 2019, 3, 10-13.

3. Cai, X.; Yang, Y.; Ringle, C.; Zhao, J.; You, L. Agricultural water productivity assessment for the Yellow River Basin. Agric. Water Manag. 2011, 98, 1297-1306. [CrossRef]

4. El-Marsafawy, S.M.; Swelam, A.; Ghanem, A. Evolution of crop water productivity in the Nile Delta over three Decades (1985-2015). Water 2018, 10, 1168. [CrossRef]

5. Xu, Z.; Chen, X.; Wu, S.R.; Gong, M.; Du, Y.; Wang, Y.; Liu, J. Spatial-temporal assessment of water footprint, water scarcity and crop water productivity in a major crop production region. J. Clean. Prod. 2019, 224, 375-383. [CrossRef]

6. An, J.B. Study on Water Consumption Law and Irrigation Scheduling of the Cotton under No-Film Transplanted Sub-Surface Drip Irrigation. Master's Thesis, Shihezi Univsersity, Shihezi, Xinjiang, China, 2009.

7. Zeng, C. The Growth Characteristics and High Water Use Efficient on Mature Grape under Extremely Drought Region. Ph.D. Thesis, University of Chinese Academy of Sciences, Xianyang, Shaanxi, China, 2010.

8. Zhang, W. Research of irrigation water usage benefit in irrigation area of Akesu river basin. Heilongjiang Sci. Technol. Water Conserv. 2012, 40, 10-12.

9. Li, J.; Zhang, M. Influence factors for Karez abandonment and its environment effects in Turpan Basin of Xinjiang Uygur Autonomous Region over last 60 years. Bull. Soil Water Conserv. 2013, 33, 239-244. 
10. Willardson, L.S.; Allen, R.G.; Frederiksen, H. Eliminating irrigation efficiencies. In Proceedings of the USCID 13th Technical Conference, Denver, CO, USA, 19-22 October 1994; p. 15.

11. Seckler, D. New Era of Water Resources Management: From Dry to Wet Water Savings; Research Report; International Water Management Institute: Colombo, Sri Lanka, 1996.

12. Jensen, M.E. Beyond irrigation efficiency. Irrig. Sci. 2007, 25, 233-245. [CrossRef]

13. Perry, C.; Steduto, P.; Allen, R.G.; Burt, C.M. Increasing productivity in irrigated agriculture: Agronomic constraints and hydrological realities. Agric. Water Manag. 2009, 96, 1517-1524. [CrossRef]

14. Crase, L.; O'Keefe, S. The Paradox of National Water Savings: A Critique of 'Water for the Future'. Agenda 2009, 16, 45-60. [CrossRef]

15. Grafton, R.; Williams, J.; Perry, C.J.; Molle, F.; Ringler, C.; Steduto, P.; Udall, B.; Wheeler, S.A.; Wang, Y.; Garrick, D.; et al. The paradox of irrigation efficiency-Higher efficiency rarely reduces water consumption. Science 2018, 361, 748-750. [CrossRef] [PubMed]

16. Humphreys, E.; Kukal, S.S.; Christen, E.W.; Hira, G.S.; Singh, B.; Yadav, S.; Sharma, R.K. Halting the groundwater decline in north west India- which crop technologies will be winners? Adv. Agron. 2010, 109, 155-217.

17. Yan, N.; Wu, B. Integrated Spatial Temporal Analysis of Crop Water Productivity of Winter Wheat in Hai Basin. Agric. Water Manag. 2014, 133, 24-33. [CrossRef]

18. Tuolunbuke, W.N. Turpan oasis agriculture: The brilliant cultural ecology by Karez. J. Orig. Ecol. Natl. Cult. 2017, 1, 9-16.

19. Cao, P.; Bai, Y.; Zhang, J. Countermeasures and suggestions for sustainable utilization of water resources in Turpan. Xinjiang Water Resour. 2011, 5, 1-5.

20. Ling, H.; Yu, Y.; Yu, R. Assessment of sustainable water resources utilization in Turpan region of Xinjiang. Yellow River 2015, 37, 70-73.

21. Statistic Bureau of Xinjiang Uygur Autonomous Region. Xinjiang Statistical Yearbook; China Statistics Press: Beijing, China, 2016.

22. Wu, B.; Liu, S.; Zhu, W.; Yan, N.; Xing, Q. An Improved Approach for Estimating Daily Net Radiation over the Heihe River Basin. Sensors 2017, 17, 86. [CrossRef]

23. Zhu, W.; Wu, B.; Yan, N.; Feng, X.; Xing, Q. A method to estimate diurnal surface-soil heat flux from MODIS data for a sparse vegetation and bare soil. J. Hydrol. 2014, 511, 139-150. [CrossRef]

24. Wu, B.; Xing, Q.; Yan, N.; Zhu, W.; Zhuang, Q. A linear relationship between temporal multiband MODIS BRDF and aerodynamic roughness in HiWATER wind gradient data. IEEE Geosci. Remote Sens. Lett. 2015, 12, 507-511.

25. Zhuang, Q.; Wu, B.; Yan, N.; Zhu, W.; Xing, Q. A method for sensible heat flux model parameterization based on radiometric surface temperature and environmental factors without involving the parameter KB-1. Int. J. Appl. Earth Obs. Geoinf. 2016, 47, 50-59. [CrossRef]

26. Xu, J.; Wu, B.; Yan, N.; Tan, S. Regional daily ET estimates based on the gap-filling method of surface conductance. Remote Sens. 2018, 10, 554. [CrossRef]

27. Wu, B.; Zhu, W.; Yan, N.; Feng, X.; Xing, Q.; Zhuang, Q. An improved method for deriving daily evapotranspiration estimates from satellite estimates on cloud-free days. IEEE J. Sel. Top. Appl. Earth Obs. Remote Sens. 2016, 9, 1323-1330. [CrossRef]

28. Tan, S.; Wu, B.; Yan, N.; Zeng, H. Satellite-Based Water Consumption Dynamics Monitoring in an Extremely Arid Area. Remote Sens. 2018, 10, 1399. [CrossRef]

29. Kong, W.; Cheng, Z.; Zhang, R. Study on greenhouse grapes under delayed cultivation water productivity by using water productivity function model. Guangdong Agric. Sci. 2014, 14, 41-46.

30. Hu, S.; Song, Y.; Zhou, H.; Tian, C. Experimental study on water use efficiency of cotton in the Tarim River Basin. Agric. Res. Arid Areas 2002, 20, 66-70.

31. Zhang, J.; Li, J.; Yan, Y. Water utilization efficiency investigation of vegetables cultured under different planting pattern in solar greenhouse in Turpan City. Chin. Veg. 2013, 22, 88-91.

32. Clarke-Sather, A.; Tang, X.; Xiong, Y.; Qu, J. The impact of green water management strategies on household-Level agricultural water productivity in a semi-arid region: A survey-based assessment. Water 2018, 10, 11. [CrossRef] 
33. Delorit, J.D.; Dominic, P.P.; Paul, J. Block. An agro-economic approach to framing perennial farm-scale water resources demand management for water rights markets. Agric. Water Manag. 2019, 218, 68-81. [CrossRef]

34. Delorit, J.D.; Paul, J.B. Promoting competitive water resource use efficiency at the water market scale: An intercooperative demand equilibrium based approach to water trading. Water Resour. Res. 2018, 54, 5394-5421. [CrossRef]

35. Razzaq, A.; Qing, P.; Naseer, M.; Abid, M.; Anwar, M.; Javed, I. Can the informal groundwater markets improve water use efficiency and equity? Evidence from a semi-arid region of Pakistan. Sci. Total Environ. 2019, 666, 849-857. [CrossRef]

36. Erfani, T.; Binions, O.; Harou, J. Simulating water markets with transaction costs. Water Resour. Res. 2014, 50, 4726-4745. [CrossRef] [PubMed]

37. Li, X.; Zhang, X.; Niu, J.; Tong, L.; Kang, S.; Du, T.; Li, S.; Ding, R. Irrigation water productivity is more influenced by agronomic practice factors than by climatic factors in Hexi Corridor, Northwest China. Sci. Rep. 2016, 6, 37971. [CrossRef] [PubMed]

(C) 2020 by the authors. Licensee MDPI, Basel, Switzerland. This article is an open access article distributed under the terms and conditions of the Creative Commons Attribution (CC BY) license (http://creativecommons.org/licenses/by/4.0/). 